Arch. hist. jap. Vol. 19, n. 3 (May 1960).

P. 509-517.

Dept. of Oral Surg. (Director : Prof. Kensaku KAWAKATSU),

Dental School, Osaka Univ., Joan-cho, Kita-ku, Osaka.

\title{
Histochemical Observations on Aminopeptidase Activity in Normal Salivary Gland.
}

\author{
正常唾液腺のアミノペプチダーゼに関する組織化学的研究. \\ Kensaku KAWAKATSU, Masahiko MORI, Tsuneo MIZUSHIMA \\ and Masaru MURAKAMI. \\ 川勝賢作, 森昌彦, 水島怕雄, 村上勝.
}

(Received January 28, 1960.)

Colorimetric determination of aminopeptidase was effected by GOMORI( 1954), who used glycyl and alanyl $\beta$-naphthylamide as a substrate. GREEN, TSOU, BRESSLER and SELIGMAN (1955) used L-leucyl- $\beta$-naphthyl amide hydrochloride. BURSTONE and FOLK (1955) adapted leucyl and alanyl $\beta$-naphthylamide in the simultaneous method for the purpose of histochemical study of those enzyme. It is recently that NACHLAS, CRAWFORD and SELIGMAN (1957) reported their Cu chelating method by employing the same substrate as BURSTONE and FOLK did. However, we regret to say that any report has, so far, hardly been made concerning the studies on aminopeptidase of the normal salivary glands of certain mammals. Under the circumstances, we believe it has interest and significance to report here on the distribution and localization of aminopeptidase of the salivary glands by employing the method of BURSTONE and FOLK and that of NACHLAS, CRAWFORD and SELIGMAN.

\section{Material and experimental procedures.}

This experiment was conducted on the salivary glands of both male and female animals such as mice, rats, guinea pigs, rabbits and dogs in the two methods stated below. According to BURSTONE and FOLK's simultaneous coupling method (1956), fresh tissues were treated after freezing and drying with hydrochloride of L-leucyl$\beta$-naphthylamide or DL-alanyl- $\beta$-naphthylamide as a substrate, $0.2 \mathrm{M}$. Tris buffer (pH 7.2) and diazotized o-aminoazotoluene (Garnet GBC). Diazotized p-nitro-o-anisidine (Diazo Red B) or p-nitro-p-amino-2,5-dimethoxy-diphenylamide (Black salt K) can be used in stead of diazotized o-aminoazotoluene. In case of stronger enzyme activity, $0.2 \mathrm{M}$. phosphate buffer ( $\mathrm{pH} 6.8$ ) is available in place of $0.2 \mathrm{M}$. Tris buffer ( $\mathrm{pH}$ 7.2). In our experiment, Garnet GBC was not used, but employed tetrazotized diorthoanisidine (Diazo Blue B).

Fresh tissues were cut into thin sections $(10-20 \mu)$ in the cryostat at $-20^{\circ} \mathrm{C}$, which were fixed in $10 \%$ formalin for 10 minutes and rinsed briefly in distilled water. We added to them $1 \mathrm{ml}$ of $1 \%$ stock substrate solution (in the two kinds used by BURSTONE and FOLK), $40 \mathrm{ml}$ of distilled water, $10 \mathrm{ml}$ of $0.2 \mathrm{M}$. Phos- 

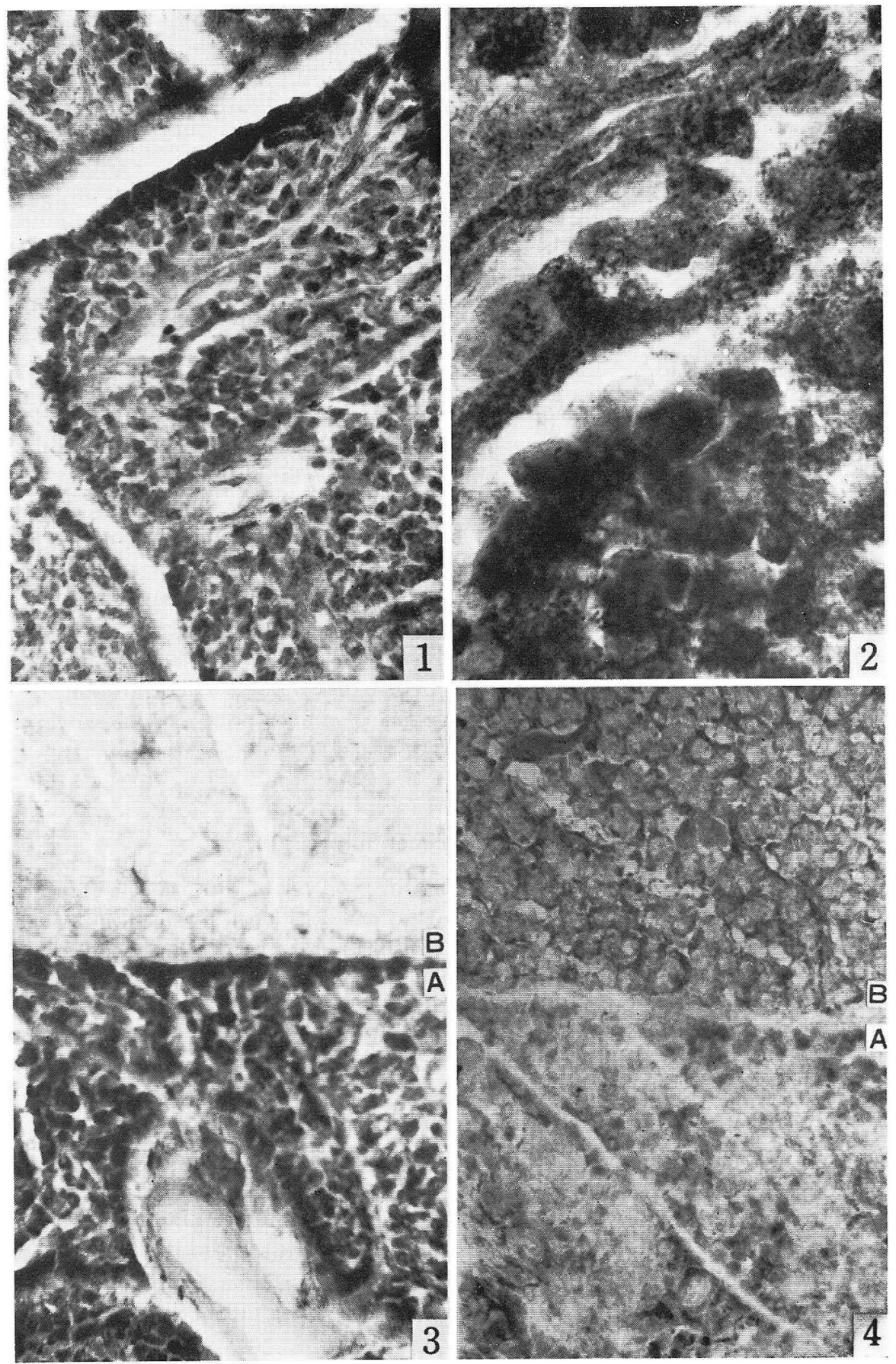
phate buffer and $30 \mathrm{mg}$ of Diazo Blue B, and incubated them for an hour at room temperature, and then mounted them in glycerin.

Furthermore in accordance with NACHLAS, GRAWFORD and SELIGMAN's method we did an experiment in the same way as mentioned above. But we mixed substrate solution $(8 \mathrm{mg} / 1 \mathrm{cc}) 1 \mathrm{ml}$, acetate buffer $(\mathrm{pH} 6.5,0.1 \mathrm{M}) 10 \mathrm{ml}, 0.85 \%$ sodium chloride $8 \mathrm{ml}, 2 \times 10^{-2} \mathrm{M}$. potassium cyanide $1 \mathrm{ml}, 10 \mathrm{mg}$ of Diazo blue B, and incubated the sections for an hour at $37^{\circ} \mathrm{C}$. The sections were rinsəd in distilled water for a short time, and after chelating in $0.1 \mathrm{M}$. cupper sulfate, we mounted them in balsam.

Histochemical studies on the aminopeptidase of salivary glands in experimental animals were performed by emploploying these both methods.

\section{Results.}

It was found that the activity of aminopeptidase of salivary glands differs in species of animals. But the results concerning the localization of enzyme were the same after the method of BURSTONE and FOLK and of MACHLAS, CRAWFORD and SELIGMAN.

In the BURSTONE and FOLK's method azo dye sometimes infiltrated into fat after mounting in glycerin since coupling azo dye is soluble in fat.

In the case of NACHLAS, CRAWFORD and SELIGMAN's method the formation of bluish fine granules were occasionally observed at the time of $\mathrm{Cu}$ chelating. As for the needed time to get the reaction in the substrate, thirty minutes were not enough except for salivary glands of guinea pig, and two hours were too long for them resulting a dark color. One hour was found to be the most proper time for incubation. When leucyl- $\beta$-naphthylamide hydrochloride and alanyl- $\beta$-naphthylamide hydrochloride compared with each other, no significant difference was obsirved as to the distribution and localization of enzyme.

Mouse.

The cellplasm of the submaxillary gland showed the most intensive activity. The intralobular duct reacted also very intensely, and especially after the NACHLAS's method dark blue granules resulted. The enzyme activity of large secretory ducts was weaker.

Also the enzyme reaction of the sublingual gland was weak. Though finer intralobular ducts gave a little enzyme reaction, thicker secretory ducts indicated no reaction at all. glands.

All of these figures illustrate the distribution of aminopeptidase in normal salivary

Fig. 1. Mouse's submaxillary gland showing most intense enzyme activity in acinar cells and intralobular duct. $\times 100$

Fig. 2. Enlargement of Fig. 1. $\times 400$

Fig. 3. Fig. A is of mouse's submaxillary gland. Mouse's sublingual gland in Fig. B shows weak enzyme reaction which is somewhat notable in intralobular ducts, whereas no enzyme reaction in secretory ducts. $\times 100$

Fig. 4. Rat's submaxillary gland in Fig. A shows moderate or slight enzyme reaction in acinar cells, but intralobular ducts are of moderate activity. Rat sublingual gland in Fig. $B$ exhibits moderate activity at the basal portions of acinar cells. $\times 100$ 

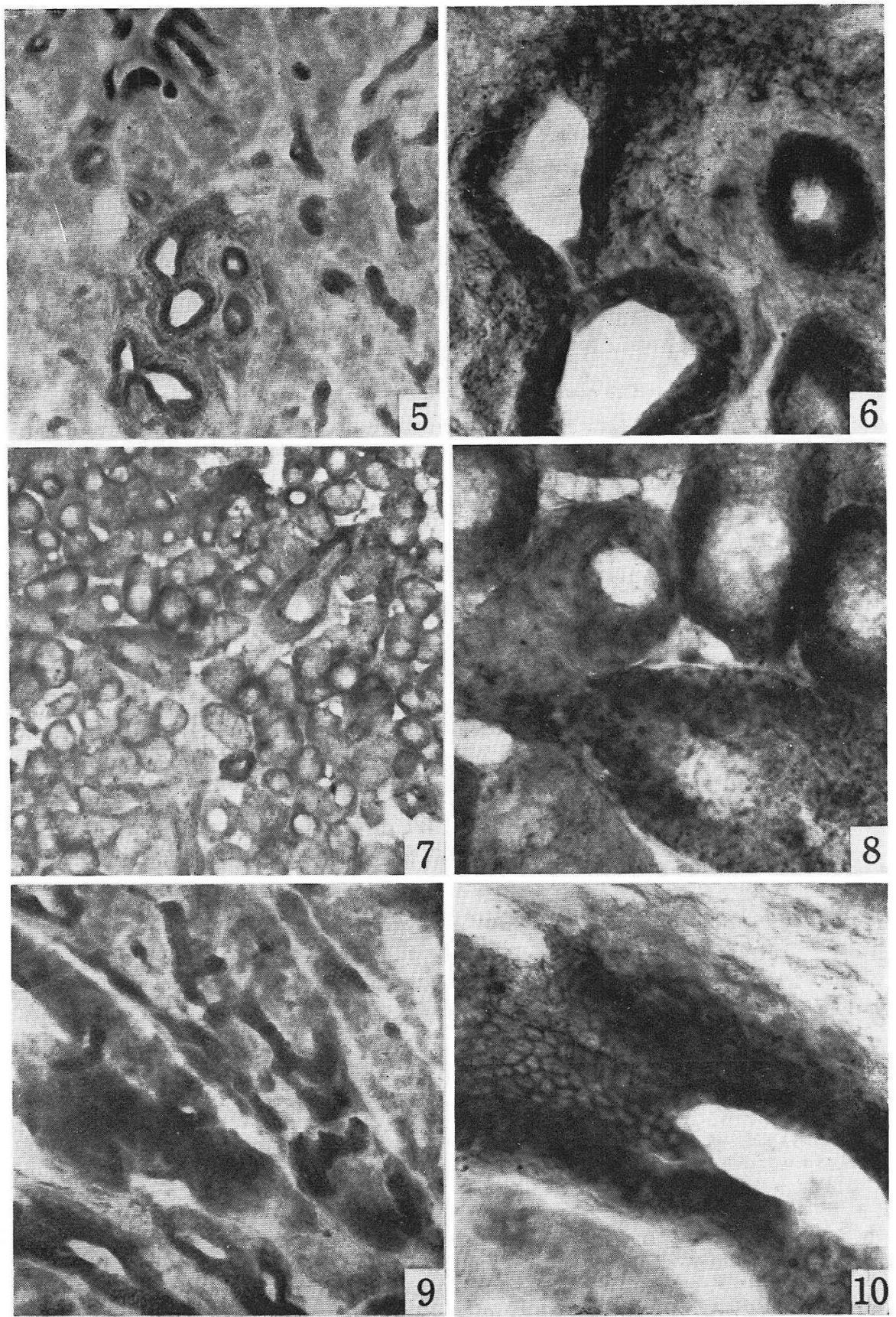
A slight reaction was seen in the duct cells of the parotid gland.

\section{Rat.}

The acinar cells of the submaxillary gland reacted moderately or slightly. Moderate activity was seen in the intralobular ducts as well. Enzyme localization of the submaxillary gland cells showed moderate activity in their basal portion.

In the parotid gland the reaction was weak, Their ducts were not of strong reaction.

\section{Guinea pig.}

Moderate activity was observed in the serous cells of the submaxillary gland. In the interlobular ducts, on the other hand, the activity was more intense, showing fine granules.

The most significant reaction was observed in the acinar cells of the sublingual gland, and simultaneously activity was strong in the ducts which contained granules.

The activity of the parotid gland cell was a little stronger than that of the submaxillary duct. Intralobular duct showed strong reaction.

\section{Rabbit.}

Intense activity appeared in the submaxillary gland cells and the most intense reaction occured in its intralobular ducts. But granules were not formed in them.

On the contary, the parotid gland was almost of no enzyme reaction.

Dog.

Enzyme showed moderate activity in the basal portion of the acinar cells of the submaxillary gland, and the reaction was in the secretory sites weak. Intralo-

Table 1. Aminopeptidase activities of acini cells and intralobular duct cells in salivary glands

\begin{tabular}{|c|c|c|c|c|c|c|}
\hline & \multicolumn{2}{|c|}{ Submaxillar gland } & \multicolumn{2}{|c|}{ Sublingual gland } & \multicolumn{2}{|c|}{ Parotid gland } \\
\hline & $\begin{array}{l}\text { Acinar } \\
\text { cells }\end{array}$ & $\begin{array}{l}\text { duct } \\
\text { cells }\end{array}$ & $\begin{array}{l}\text { Acinar } \\
\text { cells }\end{array}$ & $\begin{array}{l}\text { duct } \\
\text { cells }\end{array}$ & $\begin{array}{l}\text { Acinar } \\
\text { cells }\end{array}$ & $\begin{array}{l}\text { duct } \\
\text { cells }\end{array}$ \\
\hline Mouse & +++ & $++t$ & + & \pm & $+\sim \pm$ & - \\
\hline Rat & $++\sim+$ & ++ & ++ & + & + & + \\
\hline Guinea pig & ++ & $+++\sim++$ & ++ & $+++\sim++$ & $++\sim+++$ & $++t$ \\
\hline Rabbit & $+t$ & +++ & & & - & - \\
\hline Dog & +++ & ++ & ++ & $++\sim+$ & + & $++\sim+$ \\
\hline
\end{tabular}

Fig. 5. Guinea pig's submaxillary gland shows moderate enzyme activity in the serous cells. Interlobular and interlobular ducts containing fine granules reveal intense activity of the enzyme. $\times 100$

Fig. 6. Enlargement of Fig. $5 . \times 400$

Fig. 7. Guinea pig's sublingual gland. The acinar cells contain fine granules and show most significant reaction in their basal part. $\times 100$

Fig. 8. Enlargement of Fig. 7. $\times 400$

Fig. 9. Guinea pig's parotid gland exhibits moderate enzyme activity as seen in the submaxillary gland. Strong reaction appears in the intralobular ducts. $\times 100$

Fig. 10. Enlargment of Fig. $9 . \times 400$ 
bular ducts showed a moderate reaction, being diffusely stained. Moderate activity was also observed in the sublingual gland, the basal part of the glandular cells was deeply stained. Thus it was concluded that the aminopeptidase reaction of salivary gland was strong in the submaxiliary gland and weak in the parotid gland. In general, strong enzyme reaction was marked in the intralobular duct.
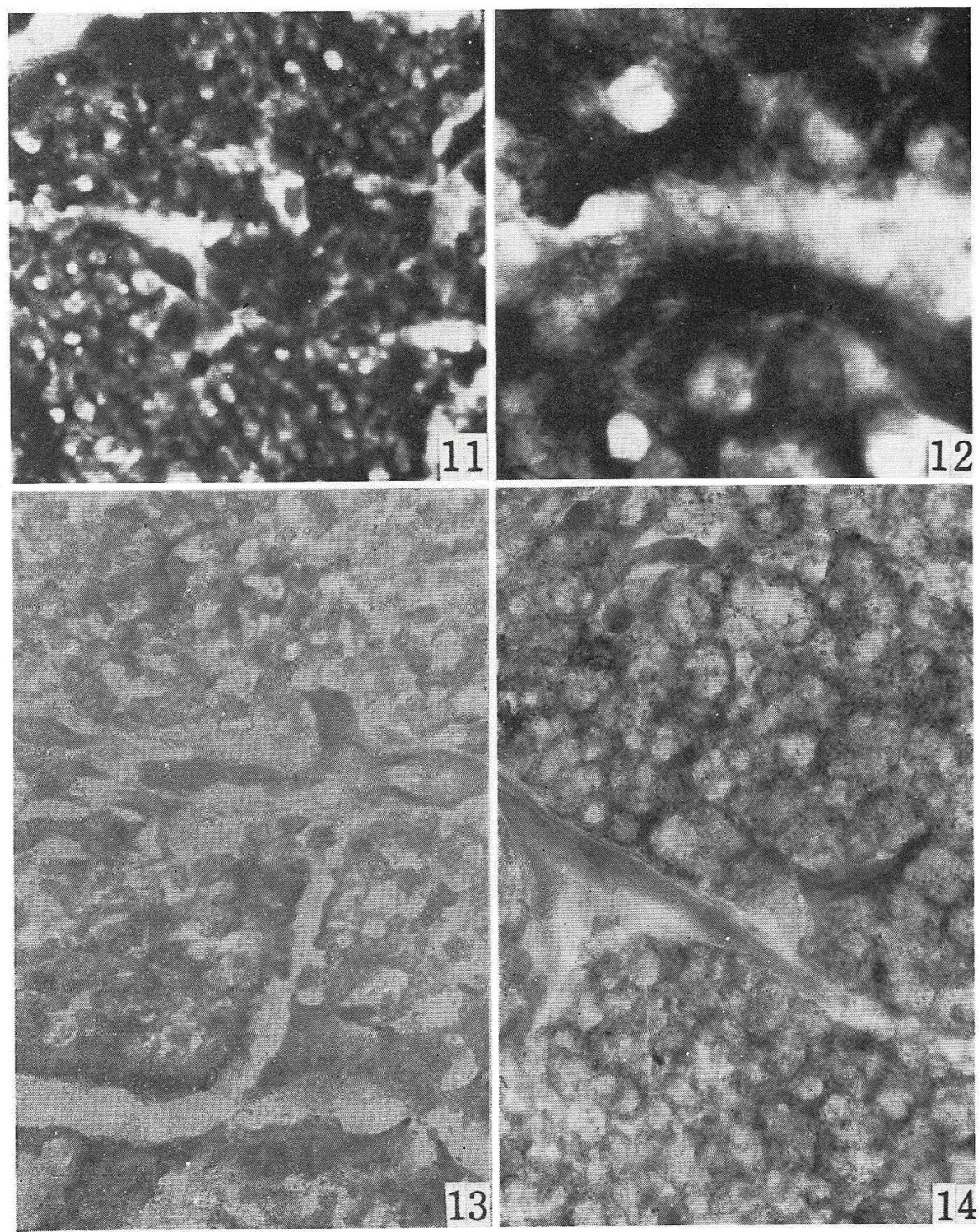


\section{Discussion.}

As a result of biological examinations of each peptidase belonging to various animals, which were conducted by BERGER, JOHNSON (1940), FRUTON (1946) and SMITH (1948) et al., it was clarified that enzyme is activated by $\mathrm{Mn}$ and $\mathrm{Mg}$, while on the contrary its activity is inhibited to a great extent by sodium citrate $\left(10^{-2} \mathrm{M}\right)$. SMITH and co-workers purified the peptidase of the intestinal mucosa and kidney of the pig. They obsarved that these extractive enzyme reacted most specifically on the leucyl peptide and slightly on the other peptide. The pure leucine aminopeptidase is recognized to be specifically reactive on DL-norvalinamide, DLaminobuthylamide, L-tryptophanamide, and L-alaninamide. It is indicated that the activity of this enzyme disappear under the effects of $0.01 \mathrm{M}$ of $\mathrm{KCN}$, and is inhibited by $\mathrm{Cu}^{++}, \mathrm{Pb}^{++}$and $\mathrm{Ca}^{++}$. On the other hand it becomes more active under the effects of KCN $(0.0001-0.0003 \mathrm{M})$. GOMORI (1954) produced $\beta$-naphthylamide of glycyl and alanyl in order to use it as a chromogenic substrate of aminopeptidase. FOLK and BURSTONE produced $\beta$-naphthylamide of leucyl and alanyl. They reported that his substrate becomes hydrolysable by aminopeptidase and is most suitable for the histochemical coupling method using these two substrate and Garnet GBC. BURSTONE also reported the result of staining of aminopeptidase under tumor or pathologic conditions. After that NACHLAS, CRAWFORD, and SELIGMAN (1957) made a report on the method of chelating coupling Diazo blue B with $\mathrm{Cu}$, which are in the naphthylamide, by incubating the tissue in the leucyl- $\beta$-naphthylamide hydrochloride and Diazo blue B.

A study on the aminopeptidase of salivary glands has not, so far, been made. We compared in detail succinic dehydrogenase, alkaline phosphatase, esterase, $\beta$ glucuronidase, $\beta$-glucosidase, $\beta$-galactosidase associate with the aminopeptidase. We employed leucyl and alanyl $\beta$-naphthylamide hydrochloride as a substrate of aminopeptidase and did not find out any difference among them, and we believe that is because these two have similar activity on salivary glands.

Serous cells of the salivary glands stained slightly in Periodic acid-SCHIFF reaction and showed moderate reaction on aminopeptidase, but on the other hand the serous cells of the parotid gland showed only a weak reaction. The activity of the aminopeptidase was observed in the basal portion of sublingual gland cells, being as remarkable as that of esterase, acid phosphatase and glycosidase, and the demilune cells contained also these hydrolytic enzyme. It was demonstrated that aminopeptidase reaction comes out stronger in the serous cells than in the mucinous cells. It is generally recognized that the serous cells of salivary glands has a stronger activity of protein metablism than that of mucinous cells.

The activity of aminopeptidase was more intensely seen in the organs of guinea pig than in those of rat.

Fig. 11. Rabbit's submaxillary gland showing intense enzyme activity in duct cells. The most intense reaction is seen in intralobular ducts which contain no granules.

Fig. 12. Enlargement of Fig. 11. $\times 400$

Fig. 13. Rabbit's parotid gland demonstrates almost no enzyme reaction. $\times 100$

Fig. 14. Dog's submaxillary gland showing moderate activity in the basal portion of acinar cells, their inner part exhibiting weak reactions and being stained diffusely. $\times 100$ 
As stated above, interlobular ducts reacted more intensely on enzyme than acinar cells. It may help explain likewise that intralobular ducts were reactive on succinic dehydrogenase, acid phosphatase, esterase and $\beta$-glucuronidase. The reason why succinic dehydrogenase showed such a high activity in the duct cells, is presumably that they contain a plenty of mitochondoria. But the cause of strong reaction of other hydrolytic enzyme has not yet been clarified. According to the study by OGATA and his co-workers, striated duct cells of salivary glands has not basal membrane. TAKIZAWA and his co-laborators found intercellular canalicular system by using electron-microscope. The striated duct cells are considered by them to be a place where saliva-a production of acinar cells-is reabsorbed. We think it is very interesting that many hydrolytic enzymes are found in these striated duct cells.

\section{Summary.}

Experiments were conducted on salivary glands of both male and female such as mice, rats, guinea pigs, rabbits, and dogs in employing both the BURSTONE and FOLK method and NACHLAS, CRAWFORD and SELIGMAN method for the purpose of seeing the distribution and localization of aminopeptidase.

1. Mouse: The most intense activity of the enzyme was observed in the submaxillary gland, but the enzyme reaction was weak in the sublingual gland.

2. Rat: The submaxillary and sublingual gland revealed moderate or slight reaction, and in the latter gland the reaction was seen in the basal portion of the cells. The parotid gland showed a weak reaction.

3. Rat: The submaxillary and parotid gland showed moderate activity of the enzyme, but the most significant reaction was found in the sublingual gland.

4. Rabbit: The submaxillary gland showed an intense enzyme activity. On the other hand the parotid gland exhibited no activity.

5. Dog: The submaxillary and sublingual gland showed moderate activity, and the parotid gland showed weak reaction.

6. High enzyme reaction were observed in intralobular ducts, especially in the striated ducts cells of certain mammals, and the enzyme activity was generally found to be weaker in large duct cells than in intralobular duct cells.

\section{内 容 自 抄.}

マウス, ラット, モルモット, 家忈, 犬の雌雄の 3 大唾液腺を摘出し, 新鮮組織 を $-20^{\circ} \mathrm{C}$ の冷濑室で $20 \mu の$ 切片とし, $10 \%$ ホルマリンで 10 分閒副定し, 短晼間 水沙後, Burstone と Folk (1956) の方法と Nachlas, Crawford, Seligman (1957)

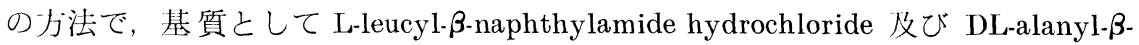
naphthlamid hydrochloride を用いて染色した。 それら両基質閒に於ける䤏素分布 に差暴は認められない。

結果の大要は表 1 に示した如くであるが，一般に用いた動物の顎下腺の漿液絧 胞は著明な反灾を示し，耳下腺細胞は反応が弱い，舌下腺細胞は基底部に強い反 忍を示す。このととは唾液腺の漿液絒胞は粘液紐胞よりも蛋白代铸の行わ机る傾 
们が強い事在示すあのである。

\section{References.}

Berger, J. and M. Johnson : The activation of dipeptidase. J. biol. Chem. 133 (1940) P. 639-640. - Burstone, M. S.: Histochemical demonstration of proteolytic activity in human neoplasms. J. Nat. Cancer Inst. 16 (1956). P. 1149-1161. - Burstone, M. S. and J. E. Folk : Histochemical demonstration of aminopeptidase. J. Histochem. Cytochem. 4 (1956). P. 217-226. - Furton, J. S.: On the proteolytic enzymes of animal tissues. V. Peptidase of skin, lung and seroum. J. biol. Chem. 166 (1946). P. 721-738. -- Gomori, G.: Chromogenic substrate for aminopeptidase. Proc. Soc. exp. Biol. Med. 87 (1954). P. 559-561. Green, M. N., K. E. Tsou, R. Bressler and A. M. Seligman : The colorimetric demonstration of leucine aminopeptidase activity with L-leucyl-ß-naphthylamide hydrochloride. Arch. Biochem. Biophs. 57 (1955). P. 458-474. - Kawakatsu, K. et al.: Histochemical studies of normal salivary glands. I. Distribution and localization of succinic dehydrogenase in human salivary gland and experimental animals. J. Osaka. Univ. Dent. 'Soc. 4 (1959). P. 421. Histochemical studies of normal salivary glands. II. Distribution and localization of esterase in salivary glands of experimental animals. J. Osaka. Univ. Dent. Soc. 4 (1959). P. 439. - Histochemical studies of salivary glands. III. Distribution and localization of alkaline phosphatase in the salivary glands of experimental animals. J. Osaka Univ. Dent. Soc. 4 (1959). P. 455. - Kawakatsu, K., M. Mori, K. Fujita and T. Tani : Histochemical studies of normal salivary glands. IV. Distribution and localization of acid phosphatase in the salivary glands in experimental animals. (Jap). Arch. hist. jap. 19 (1960). (In press)Kawakatsu, K., M. Mori, M. Fukuda and M. Deguchi : Histochemical demonstration of $\beta$-glucuronidase, $\beta$-galactosidase, $\beta$-glucosidase in normal salivary gland. Arch. hist. jap. 19 (1960). (In press). - Nachlas, M. M., D. T. Crawford and A. M. Seligman : The histochemical demonstration of leucine aminopeptidase. J. Histochem. Cytochem. 5 (1957). P. 264-268. - Smith, E. L.: The peptidase of skeletal, heart, and uterine muscle. J. biol. Chem. 173 (1948). P. 553-569. - Takizawa, N., T. Hashizume and T. Shimada: The electolonemicroscopic construction of the secretory tube of the salivary gland. Acta. Path. Jap. 7 (1957). P. 379. 